\title{
Reconsidering Cultural Representation with Field Theory: Continuity and Change in the Discursive Construction of Italy and the Italians in England from 1680 to 1830
}

\author{
Christopher Thorpe ${ }^{1 *}$ \\ ${ }^{1}$ University of Exeter, UNITED KINGDOM \\ *Corresponding Author: c.m.thorpe@exeter.ac.uk \\ Citation: Thorpe, C. (2019). Reconsidering Cultural Representation with Field Theory: Continuity and \\ Change in the Discursive Construction of Italy and the Italians in England from 1680 to 1830, Journal of \\ Cultural Analysis and Social Change, 4(1), 02. https://doi.org/10.20897/jcasc/5845
}

Published: July 19, 2019

\begin{abstract}
This article demonstrates the comparative merits of Bourdieu's field theory, as opposed to the composite theoretical model set out in Edward Said's Orientalism specifically and critical normative approaches to theorizing constructions of otherness more generally, as the basis for a more analytically differentiated account of cultural representation. Crucially, one capable of acknowledging the generative effects negative constructions of the other have for informing the contexts in which positive constructions arise and how the interplay of both negative and positive discursive constructions inform continuity and change in the discursive representation of the cultural other over time. Drawing on secondary historical data relating to discursive representations of Italy and the Italians in England during the period 1680 to 1830, the argument is made that both negative and positive discourses of Italy and the Italians arise out of and inform relations of conflict and cohesion conjoining agents at an intra-, as opposed to inter-, cultural level. It is the variable conditions of fields which determine agents' dispositions towards representing the other either negatively and or positively. The article concludes by reflecting on the limits of the 'Saidian' legacy for theorizing cultural representation and calls for the analytical significance of positive constructions of the other to be further problematized and explored.
\end{abstract}

Keywords: cultural representation, discursive representations, orientalism, Said, Bourdieu, field theory, England, Italy

\section{INTRODUCTION}

Edward Said's Orientalism (1978) is arguably the classic study in cultural representation. Bringing into dialogue Foucault's (post-)structuralism and Gramsci's theory of hegemony, Said deployed a critical theoretical model and methods to bring into sharp relief the façade of Western representations of the Orient and the forms of violence - literal and symbolic - implicated in their realization. In terms of its wider significance, and in ways that Said could never have fully anticipated at the time, Orientalism marked a defining moment in the constitution of cultural representation and constructions of otherness as objects of scholarly discourse (Sax, 1998). Some forty years on, Orientalism has become a 'touch-stone and key source of inspiration for scholars in the field of literary, critical and cultural theory, especially in post-colonial studies' (Varisco, 2007: 68). According to Joffe (2007: 78), the critical normative approach to cultural representation to have grown up in the wake of Orientalism has become a 'stifling orthodoxy...thanks to having permeated into countless fields' - one organised around an 'all-engrossing emphasis 
on domination, submission... and the evils of discourses, regimes, hegemonies, global capitalism, neoliberalism, and other phenomena of the human world' (Lewis, 2007: 777).

Within anthropology, a discipline organised around the Other, and representations thereof, it is hard 'to find a book by a historian or anthropologist of 'non-Western culture that does not include some gesture of obeisance to Said' (Sax, 1998: 292) ${ }^{1}$. According to Lewis (2007: 776), to broach constructions of otherness in anything less than critical and morally condemnatory ways is to run the risk of being charged with 'complicity'. By contrast, or perhaps precisely because of this, sociologists have demonstrated markedly little interest in the subject of cultural representation ${ }^{2}$. Where they have done, the tendency has been to position themselves normatively and thematically within the Saidian tradition. The work of Steinmetz (2007, 2008), for example, deploys field theory to explain differences in ethnographic accounts of the colonial other across a range of German colonies during and after World War Two. More recently, Guhin and Wrytzen (2013) have called for sociologists to (re-)read Orientalism, lest their analyses serve to perpetrate a range of 'epistemological violences' embedded within orthodox forms of sociological reasoning and theoretical constructs.

Representations of the other comprise discursive artefacts and as such can serve as vehicles for negative expressions of power e.g. reification, stereotypification and generalization; but they are much more than this too. A central contention of this paper is that discursive representations work to depict the other more or less negatively and or positively - at least as understood through the eyes of those wielding the discourse. The distinction between negative and positive discursive representations can be understood in terms of 'positioning'. Negative representations position the other in a relationship of inferiority to those doing the representing, whereas positive representations position the other as superior in some or another way. Negative and positive discursive representations are dialectically bound and co-constituting. That is to say, negative representations make possible and inform the relational contexts e.g. 'fields', in which the other comes to be understood positively e.g. as an object of veneration, emulation and edification, and vice versa. Positive discursive representations form the backdrop against which agents are disposed towards seeking out and 'knowing' the other in more complex, differentiated and 'reality congruent' ways. Negative representations tend to dispose agents away from engaging with the other.

Scholars have devoted vast amounts of time and effort to demonstrating and deconstructing the negatively constraining dimensions of cultural representation. Far less attention has been trained on exploring the conditions under which the other is constructed positively, how in turn positive representations relate to and are shaped by their negative counterparts, and how the interplay of both negative and positive discursive representations inform wider patterns of continuity and change in the historical constitution of the other. This article seeks to develop a more comprehensive account of the processes driving continuity and change in the discursive rendering of the other, which it does by drawing on Bourdieu's field theory and the work of scholars who have sought to advance field theory across different empirical domains (Gorski, 2013; Krause, 2018; Sapiro, 1992; Steinmetz, 2007, 2008). The argument is made that field theory provides the basis for a more analytically differentiated and theoretically versatile apparatus for theorizing cultural representation. Crucially, one capable of holding in its purview simultaneously the conditions under which both negative and positive discursive representations of the other arise and how and why particular discursive representations are reproduced, revised and or rejected. The central claim on which the article rests is that it is the 'variable conditions' of fields (Krause, 2018), and the shifting relations between habitus and capital therein, which determine whether agents are disposed towards representing the other more or less negatively and or positively.

The article begins by critically (re-)reading Said's Orientalism from a cultural historical sociology perspective. A flawed text on numerous levels, nonetheless Said's Orientalism remains an instructive point of (negative) reference for constructing an alternative model of cultural representation grounded in field theory. The second part of the article explicates how field theory can be adapted to cast light on the various dynamics by which actors - individual and collective - seek to distinguish and differentiate their claims to know and represent the other. The third part of the paper provides a worked example of the ways field theory can be used to capture and explain continuities, diversification and changes to, the discursive representation of the cultural other. It does this with specific reference to the case of representations of Italy and the Italians in England during the period 1680 to 1830. The data used

\footnotetext{
${ }^{1}$ See also Dirks (2004) for a critical survey of the impact of Said's Orientalism on anthropology in Western Europe and North America. In particular, the role played by Orientalism in relation to what has since been referred to as the 'crisis of representation'.

2 The work of Bryan Turner $(1978,1989,1994)$ is the most notable exception to this general rule. That said, however, Turner's work on orientalism forms part of his wider concern with inter-societal conflict as understood through the master category of globalization. More recently, the work of Go (2013a, 2016) has engaged with conceptions of the colonial other as part of a wider critical project aimed at interrogating sociological theoretical concepts and modes of reasoning through the framework of an emergent postcolonial social theory.
} 
here derive from an in-depth cross-disciplinary analysis of a range of sources e.g. textual artefacts such as grand tourists travel narratives and literary works, and secondary literature and historical studies. These data were used to reconstruct and analyse the habitus of cultural producers, structural properties, ideologies, logics and relations organising and between fields (Sapiro, 2012).

\section{ORIENTALISM: A CULTURAL HISTORICAL SOCIOLOGICAL (RE-)READING}

Like all texts which attain to classic status, Orientalism does so on account of its generative capacities. Said's appropriation of Foucault's theory of discourse comprises one of the earliest introductions of the latter's work to Western audiences (Goodwin Smith, 2009). Orientalism was key to situating Foucault and post-structuralism more generally at the heart of post-colonial studies. Following Orientalism, analysis of the other as a product of discourse and site for the negative expression of power has proliferated in relation to a range of cultural others (Khare, 1990; Cassano, 2012; Chovanek and Molek-Kozakowska, 2017). While all 'others' are discursively constituted, not all discourse is organised around or works to position the other in a relationship of inferiority to those doing the representing.

Said's failure to distinguish and differentiate between negative and positive forms of discursive representation is understandable. After all, Orientalism was explicitly intended to be a polemical text (Said, 1987). For the argument I am making here, however, the distinction is a crucial one. This is so in the following ways: first, while all discursive representations contain the 'bad seeds' of reification, stereotypification and generalization, not all representations work to position those being represented in a relationship of inferiority to those doing the representing; second, neglecting to acknowledge this works to obscure an appreciation of the generative consequences negative discursive representations have for informing the contexts in which positive representations arise (and subsequently vice-versa). It also precludes an understanding of how the form and content of negative and positive discursive representations intimately impinge on and shape one another; and third, recognising the difference between positive and negative representations opens up a space in which to consider how the interplay between the two connects up to and informs continuity and change in the discursive rendering of the other over time.

Precisely because, not in spite of, the analytically curtailed framework Said employs in his analysis, Orientalism remains a highly instructive text. Specifically, for the purposes of plotting the analytical coordinates with which to map-out a more differentiated and versatile account of cultural representation. In adopting a longue durée-inspired approach to the history of Western representations of the Orient, Said was forced to grapple with a number of general-level analytical issues which any historically-based account of cultural representation, critical normative or otherwise, must attend to and resolve. Said failed to adequately resolve these issues (Ahmad, 1992; Porter, 1993). Notwithstanding this, I am suggesting here that (re-)reading Orientalism through the nexus of analytical concerns and problematics characteristic of historical cultural sociological modes of reasoning allows for these general-level analytical issues to be reformulated in terms which field theory is far better equipped and able to grasp. With this in mind, there are four main general-level analytical issues worthy to note.

\section{Continuity and Change}

Why do particular discursive representations of the cultural other persist over time and space, others are revised and change altogether, while others still are rejected and fall out of view? A central claim of Orientalism centres on the historical longevity and continuity of Orientalist discourse. Rhetorically at least, Said (2005 [1978]: 21) claims for Orientalism the status of a genealogy; in actuality his approach to the data is resolutely archaeological. This is deeply problematic, not least because Foucault's archaeological method conceives history as a series of wholly distinctive and radically differentiated 'epistemes' e.g. pre-classical, classical and modern (Foucault, 2002 [1969]). Epistemes comprise the bounded normative and ideational structures in which social life unfolds. Viewed synchronically, from within the self-referential confines of a particular episteme, historical change transforms the objects of discourse in new and unprecedented ways. On this view, the continuity of Orientalist discourse cannot be accounted for. In the replacing of one episteme with another the world and everything within it is brought to life anew. The question begs: by what means does Orientalist discourse retain its historical longevity and cumulative capacity?

\section{Cultural Transmission}

How and by what means are discursive representations of the other transmitted to and between actors? In effect, this is a cultural transmission issue and one which Orientalism fails adequately to address. Irrespective of the cultural entities in question, an historical account of cultural representation must be able to identify and explicate the mechanisms by which discursive constructions of the other are transmitted. Either synchronically e.g. to and between actors at a particular historical moment; and or diachronically, by which is intended inter-generationally. Orientalism contains very few clues at all, if any, as to how Orientalist discourse once airborne, is passed on and 
transmitted between actors. Foucault (2002 [1969]; 1984 [1968]) grants absolute autonomy to the discursive realm. The result is that discourse is severed from its moorings in the mundane world of everyday social (inter-)actions (Reed, 2013). On this point, Steinmetz (2007:26) is critical of Said's 'discursivism', which he rightly claims fails to demonstrate how discourse connects up to the 'psychic' and 'social' levels. Furthermore, conceived as the outcome of the aggregate and partially unintended consequences of collective human (inter-)actions, changes at the level of the episteme are elevated to the 'untheorizable' plane of 'trans-historical' breaks and ruptures (Alexander, 2003). As such, the notion that discourse can be purposively modified, revised and or rejected by actors subject(ed) to it is closed-off to view.

\section{Discursive Diversity}

How and under what conditions does the cultural other come to be understood and represented through a range of contradictory - negative and or positive - discursive representations? In an afterword to his critics penned in 1997, Said (2005 [1978]: 340) declared that Orientalism was a 'partisan book, not a theoretical machine'. This is most evident in Said's highly selective use of the 'data'. The animus driving the work of Foucault and Gramsci is resistance. Both Foucault and Gramsci conceive resistance as a necessary and inevitable correlate of power. Power begets the very discursive categories which seek to resist it. As such, where there exists 'discursive hegemony' (Said, 2005 [1978]: 340), material and or discursive forms of resistance are necessarily brought into being. Orientalism contains no attempt to track the emergence of resistive discursive formations as they arise along-side the hegemony of Orientalist discourse. The result is an overly simplified and undifferentiated account of discursive representation, which Said projects onto the image of an equally undifferentiated and homogenous collective Western subjectivity.

\section{Discourse and Power}

Which came first the representation or the relations? Whether or not Orientalist discourse drives colonialism, or vice versa, is not clear in Orientalism (Chibber, 2018); neither is it inconsequential. In actuality this is an empirical, as opposed to theoretical question, and one which would require to be carefully reconstructed by the analyst as it pertains to a particular historical moment. The obvious response would be that both material and discursive forms of power are at play in the making and remaking of the Other. But how the two interweave and impinge on one another is never unpacked or made clear in Orientalism (Chibber, 2018). Said's presentation of the data suggests that the hegemony of Orientalist discourse is the result of colonialism. In the 'caricatured version' of Orientalism carried around in the practical consciousness of many scholars (Iskander and Rustom 2010), this has tended to be read as saying that that colonial domination results in discursive formations which map squarely onto and work to reproduce the binary logic of dominator/ dominated.

In part, the seductive power of this imagery is a function of Said's highly selective presentation of the data; it also points towards his failure to reconcile the materialist basis of Gramsci's theory of hegemony with Foucault's discursive account of power (Porter, 1993). If discourse is autonomous then it cannot be colonialism which determines its form and content; if it is discourse which drives colonialism how are we to account for the enduring enmity towards the East on the part of the West without recourse to some atavistic and or reductionist form of reasoning? The important point to make here is this: negative and positive discursive representations of the other arise out of and inform struggles and solidarities organised around the accumulation of both material and discursive forms of power. As we shall see with the example of representations of Italy and the Italians in England, once objectified in modes of perceiving, texts, practices etc. discursive accounts of the other are taken up, reappropriated and mobilized along the relations of conflict and cohesion conjoining agents within fields. Moreover, agents appropriate and deploy their knowledge and experience of the other as resources for negotiating, preserving and or changing the social-relational and material dimensions of the fields in which they are positioned.

\section{REPRESENTING THE OTHER WITH FIELD THEORY}

Field theory provides the basis for an analytically differentiated and theoretically versatile account of cultural representation: one capable of holding in its purview critical normative modes of seeing, without being reducible entirely to them. Field theory allows us to identify and track the relations and pathways through which both negative and positive representations of the other arise and impinge on one another, as well as capturing how the interplay between the two informs continuity and change in the discursive construction of the other across time and social space. In place of the strangely seductive but overly abstract image of one culture eyeing up and scrutinising the other from afar, field theory enables for a bottom-up and empirically-led model of cultural representation. One which recasts fields as the intra-, as opposed to inter-, cultural arenas in which representations of the other are produced, reproduced and or change.

Objectified in the modes of conceiving and perceiving, practices, and a wide range of cultural artefacts, representations of the other are wrapped up in and constituted through forms of discursive practice. Discursive 
practices are rooted in the 'classificatory schemes' and modes of vision and division generated by a socially-marked habitus (Bourdieu and Wacquant, 1992). Discursive constructions of the other are shaped by the amount and types of capitals e.g. economic, cultural and social, acquired by and embedded in the habitus (Bourdieu, 1986). Particularly important here is the amount and types of cultural capital agents possess. Cultural capital e.g. formal education and culturally valorised forms of knowledge, shapes which aspects of the other agents direct their attention towards. Similarly, the amount of cultural capital agents are able to draw on determines the content of the discourses they generate, enabling and constraining them to express and objectify their conception of the other in a given way. Conversely, the amount and types of capital agents accrue shapes their capacity to 'decode' discursive accounts of otherness. The amount and types of capitals necessary to produce and or decode a particular discourse testifies to its 'legitimacy', and hence, 'cultural value' e.g. 'symbolic capital'.

Discursive representations of the other are constructed from various forms of capital and the claims to knowledge embedded in discursive representations comprise forms of capital in relation to particular fields. It is worth to emphasize this point. Reconceived as capitals, it becomes possible to account for the mechanisms by which discursive representations of the other are transmitted both synchronically - within and between particular fields - and diachronically too, as part of the inter-generational transmission of capitals whereby parents seek to inculcate particular forms of socially-valorised interest and knowledge into their offspring. It is the variable conditions of fields, and the shifting relations between habitus, capital and field therein, which determine continuity and change in the discursive representation of the other. How the other is conceived is informed by and informs the relations of conflict and cohesion conjoining agents across a range of more or less autonomous fields. More specifically, whether or not the other is represented positively and or negatively, is contingent on: the habitus and capitals of the producer; the organisation of the field and position-taking they occupy therein; and the position of the field in the wider architecture of fields.

Discursive representations of the other are realised and objectified at the point of intersection between a socially-marked habitus and field position. The concept of field refers to a 'network, or configuration of objective relations between positions', which operate as an aggregate of 'position-takings' agents (habitus) are more or less disposed to occupy depending on the amount and type of capitals available to them (Bourdieu and Wacquant, 1992: 97). All fields are 'force-fields', playing host to solidarities and struggles between actors - individual and collective - as they collude and compete to accumulate the stakes on offer e.g. field-specific forms of capital (Bourdieu, 1995). Underpinned by Saussure's relational account of meaning, the positions constitutive of fields are constituted by and through relations of difference (Bourdieu, 1993). Field positions, and the discursive representations emanating from them, are simultaneously enabled and constrained by the structure of relations conjoining them. Fields are characterised by varying levels of 'autonomy' (Bourdieu, 2000). Precisely because fields are not structurally determined but instead refer to processual relations extending through time and space, they are shaped by actions and relations occurring within adjacently-positioned fields. Fields with high levels of autonomy e.g. 'restricted fields' such as mathematics and poetry, are little influenced by 'external causal chains or mechanisms' (Go and Krause, 2016: 10), albeit forces external to fields are always refracted therein in one way or another. The more autonomous the field 'the more it is capable of imposing its specific logic, the cumulative history of its particular history' over the habitus therein (Bourdieu and Wacquant, 1992: 105), whereas the inverse holds true for fields characterised by low levels of autonomy.

Fields are characterised by and demonstrate certain 'logics', some of which are universal and found in all fields, while others are particular to some fields and not others. 'The 'logic' of a given field refers to the 'rules of the game' played therein (Bourdieu, 2000). One such universal logic is the division between dominant and subordinate players. Dominant players, or groups of players, possess the capacity to define as 'legitimate', or not, the range and types of moves players in the field can make, the value of the capitals players possess, and, by extension, the positions they are able to occupy. A particularly significant dimension of the struggles to occur within fields for the analysis I am undertaking here comprises 'classification struggles' (Bourdieu, 1993, 2000). These are forms of struggle organised around attempts to (re-)classify and define as legitimate, the particular claims to knowledge embedded in forms of discursive representation (Gorski, 2013). The notion of 'classification struggles' and the positions agents take up as part of those struggles is central for capturing the dynamics disposing agents towards representing the other either negatively and or positively. Moreover, whether the claims to knowledge embedded within a particular discursive representation are understood as legitimate or not, directly determines the likelihood that it is taken up by other players within the field and reproduced, revised and or subsequently comes to be rejected.

\section{ENGLISH REPRESENTATIONS OF ITALY AND THE ITALIANS: 1680-1830}

At any given historical moment there exists a dominant assemblage of discursive representations of the cultural other. These comprise socially legitimate ways of perceiving, understanding and representing the other - in this 
case Italy and Italian culture - available to those situated within -in this case- English culture. Italy and Italian culture have been highly influential in the history English culture and identity formation. The following analysis tracks continuities, the diversification of and changes to the ways, Italy and the Italians were represented in England during the period spanning approximately $1680-1830$. The timeframe dealt with here is a highly significant one. It represents the period during which English upper-class interest in and engagement with Italy and Italian culture was at its highpoint. Significantly, it also signals the earliest moments in the wider historical shift towards increasingly positive discursive accounts of Italy, Italian culture and the Italian people in England and later Britain (Thorpe, 2009). It is during this period that discursive representations of Italy, contemporary Italian culture and the Italian people begin to diversify in a range of contradictory ways. Many of the discursive representations forged during this period continue to inform the modes of seeing Italy and the Italians characteristic of British culture in the present day.

For the purposes of analysis the timeframe is divided into two analytically distinct but overlapping periods: the first, spanning approximately 1680 - 1780; and the second, spanning approximately 1780 - 1830. Throughout the former, representations of Italy and the Italians are organised almost exclusively around a simple binary opposition: Italy's Classical and Renaissance past is revered and contemporary Italy and the Italians are reviled. Exceptions to this general rule comprise the discourses of the Italian landscape as 'picturesque', and Italian opera as the finest example of its kind in Europe. In the work of the first generation of romantic poets, specifically Lord George Byron (1788 - 1824) and Percy Bysshe Shelley $(1792$ - 1822), contemporary Italy and the Italian people are reconstituted in markedly positive and laudatory terms. Elaborated most explicitly in the poetic works of these two men, the romantic rendering of Italy and the Italians grew up alongside, as opposed to entirely displacing, the focus on Italy's Classical and Renaissance past, and the still largely hostile treatment of contemporary Italy, Italian culture and the Italian people.

\section{CLASSICAL AND RENAISSANCE ITALY: 1680-1780}

During the period 1680 - 1780, claims to know and represent Italy and the Italians derive almost exclusively from fields dominated by the upper class. During this period habitus and field are poorly differentiated. As such, the habitus of field incumbents are more or less interchangeable. Upper-class identity is organised around consensus and conformity far more than it is oriented towards distinction achieved through differentiation. It is not until the mid-point of the $18^{\text {th }}$ century, when the social basis of fields steadily begins to diversify and the conditions under which the autonomisation of fields becomes possible, that the differentiation of discursive representations can take place. As we shall see, the slow but steady diversification of the social composition of fields corresponds with the diversification of possible modes of knowing and representing Italy and the Italians characteristic of this period.

Positive discursive accounts of Italy were refracted almost entirely through the prism of classicism. The education of the English upper class was organised around the accumulation of high levels of classical knowledge and learning. The setting of the classical curriculum in England can be traced back to St. Paul's Grammar School in 1509 and forms part of the enduring influence of Renaissance humanism imported into England from Italy during the $16^{\text {th }}$ century (Simonini, 1952). Of most prominence here were classical Roman models from 'the $1^{\text {st }}$ century BC to AD14, the world of Julius Caesar then Augustus' (Lane Fox, 2006: 2). The appeal of the classical authors centred on their perceived didactic value in practical matters, such as farming (Hesiod and Virgil), warfare (Livy, Frontinus, Aelian), mathematics (Euclid), architecture (Vitruvius), education (Plutarch) and moral and political behaviour (Cato, Cicero, Augustus etc.) (Ogilvie, 1960). Read as literary works, the classical authors were regarded as exemplary in the virtues of order, symmetry, balance and restraint (Highet, 1949).

The hegemony of upper-class representations of Italy as home to classical Roman and Renaissance civilization is an index of the comparatively lowly differentiated status of fields during this period. The high-levels of classical learning consolidated in the upper-class habitus strongly shape the collective response to the crisis of legitimacy resulting in the regicide of Charles $1^{\text {st }}$ in 1649 (Ayres, 1997). Regardless of political persuasion, members of the upper class mobilised and appropriated forms of classical Roman discourse as part of a collective attempt to consolidate their increased powers and status within the post-revolutionary political constitution. The civic values, political constitution and stratified society of Republican Rome meant that 'the dangers it faced not just from Julius Caesar and autocracy....all become compound metaphors for the state of England in the decades following 1688' (Johnson, 1967: 17). Imaginative literature during the late $17^{\text {th }}$ and early $18^{\text {th }}$ centuries frequently explored and extended the analogy of the Roman Republic to the English Civil War. Most notably in the Elizabethan dramatist Ben Jonson's Sejanus (1605), John Dryden's Annus Mirabilis (1666), and Joseph Addison's Cato (1711).

Similarly within the intellectual field, the legacy of imperial Rome provided a fertile terrain from which to extract valuable lessons from Posterity, the dominant conception of historiography throughout the $18^{\text {th }}$ century (Leffler, 1978; Spadafora, 1990). Prominent Enlightenment thinkers such as David Hume, Edward Gibbon and Edward 
Burke, each stood with one foot in the intellectual and political fields, occupying positions 'which recognised and reflected on the interpenetration of culture and politics' (Black and Gregory, 1991: 9). By way of the homology of positions to obtain between particular intellectual formulations and political ideologies, the discourse of Italy as a land of the classical past was carried on and reaffirmed in Gibbon's celebrated History of The Decline and Fall of the Roman Empire (1788). A Whig in politics and 'a modernist in philosophy and religion', Gibbon claimed that the idea to write the History came to him while on tour in Rome (1763 - 1765) (Pocock, 1993: 144).

Classical learning and knowledge oriented the upper class towards the civilizations of ancient Rome and the Renaissance respectively, but it was experience of these civilizations in situ which consolidated their status as the premier expression of cultural and moral refinement within the hierarchy of English taste proclivities. By 1700, the Tour of Italy was a defining practice in the formation of the upper-class habitus, integral to both the moral and aesthetic edification of the upper-class tourist (Black, 1992) ${ }^{3}$. Inspired by the value conferred on foreign travel by the classical authors (Dalby, 2000) and informed by the Post-reformation spirit of learning 'which valued empirical knowledge over abstract speculation or look learning derived merely from tradition' (Ousby, 1990:9), the Tour of Italy was considered the highpoint of the Grand Tour (Black, 2003).

Travel to Italy and exposure to classical and Renaissance culture profoundly shaped the cultural practices and taste dispositions of the English upper class. Displays of knowledge and attempts to emulate classical Roman and Renaissance styles and models across almost every sphere of the creative arts passed virtually unchallenged throughout the $18^{\text {th }}$ century. Sir Joshua Reynolds, the first President of the Royal Academy of Arts, was an ardent advocate of the study of the Italian masters. For Reynolds, who spent some two years in Italy (1749 - '52) studying the 'Grand Style' of the Renaissance masters, travel to Italy comprised an indispensable part of an artist's education 'and in some cases essential to securing patronage' (Black, 2003: 181). Reynold's influence in founding the Royal Academy in 1768 represents a defining moment in the institutional consecration of Italian travel as a highly valued form of capital within the fields of painting and sculpture respectively.

Upper-class evaluations of contemporary Italian civilization were almost entirely negative. The high levels of cultural capital orienting upper-class attention towards classical and Renaissance civilization, awareness of England's rising status throughout the century as a 'colonial superpower', and the perceived threat of papal Rome, strongly influenced the discursive parameters within which English tourists' evaluations of modern Italy and the Italians were framed. Only Italian opera and the picturesque natural scenery of the peninsula drew positive evaluations. This is evident from the travel narratives kept by upper-class tourists while abroad. Travel narratives were used to document tourists' itineraries, experiences and observations on a wide range of Italian social customs and cultural practices, as well as playing an important role in 'affirming communal stability' among the upper class (Spacks 1980: 204). In addition to this, travel narratives were a key site for the production of novel forms of discourse, which either fed back into and affirmed, altered, and or challenged pre-existing discursive accounts of Italy and the Italians. The practice of swapping and reading travel narratives was popular among tourists, albeit one confined to an informal association of upper-class networks. However, as the number of upper-bourgeois writers and tourists began to increase from around 1750 onwards, the practice of writing travel narratives became subject to increasing commercialisation (Turner 2001: 1).

Particularly important for understanding the formation of the sub-field of travel narratives within the wider field of literature were the periodicals, The Monthly and Critical Reviews. Established in 1749 and 1756 respectively, the consecrating power of these publications grew throughout the century as the number of travel narratives sent to them for review steadily increased. By the final third of the century, travel writing was established as a sub-field in its own right, 'a site of struggle for competing claims to moral virtue - claims which are frequently expressed in the gender inflected language of class and nation' (Turner 2001: 55). As such, upper-class travel practices were increasingly challenged and subject to derision by bourgeois authors and writers. The Tour of Italy was reframed as extravagant and unpatriotic, leading to vast sums of money being frittered away on foreign goods and services. As the century progressed, upper-bourgeois travellers and writers came increasingly to imagine themselves, as opposed to their upper-class counterparts whom they regarded as effete carriers of cosmopolitan ideals, as the legitimate proponents of English national identity (Black, 1992, 2003).

Tobias Smollett's travel narrative, Travels through France and Italy (1766), comprises a particularly well-known example of the rising condemnation of upper-class travel practices to and in Italy characteristic of an increasingly self-confident and critical bourgeois audience (Turner, 2001; Sena, 1968). A surgeon-cum-author, Smollett's position-taking self-consciously sought to assert and display his bourgeois values, attitudes and tastes through the medium of a 'splenetic narrator' (Smollett, 2010 [1766]). The attribute of 'spleen', understood as an affliction particularly prevalent among the 'over-educated classes', was recognised within the field as a specifically English malady deriving from the damp climate (Sena 1968: 355). Smollett's position-taking was forged in direct opposition to that of the allegedly characterless 'upper-class cosmopolite' whose class-based identity was regarded among

\footnotetext{
${ }^{3}$ Throughout the $18^{\text {th }}$ Century the importance of cultivating one's aesthetic sensibilities and capacity for discernment in
} matters of Taste, or 'virtu' as it was known then, was regarded as essential to making sound moral judgements. 
bourgeois writers as 'non-distinct' and 'indistinguishable' from the faceless herd from which (s)he derived (Turner 2001: 60). In adopting a splenetic persona and narrative style, Smollett was engaged simultaneously in a strategy of literary distinction aimed at increasing the marketability of his narrative, at the same time as marking out a dominant position within a predominantly bourgeois field.

\section{ROMANTIC ITALY: 1780-1830}

The emergence of a historically novel constellation of positive discursive representations of contemporary Italy and the Italian people is first formulated in the work of the romantic poets, Lord George Byron and Percy Bysshe Shelley. The romantic rendering of Italy was forged from the confluence of changes occurring to and within the field of cultural production within England throughout the final third of the 18th century. Of these changes, particularly important are: the decline of religious and aristocratic forms of patronage and the concurrent rise of commercial forms of printing and literature; the formation of a range of novel positions and position-takings taken up by an emergent class of professional bourgeois authors; and the perceived threat this was understood to pose to the nature and status of Art as understood from the restricted wings of the fields of literature and poetry.

From the mid-point of the $18^{\text {th }}$ century, the modes by which literary artefacts were produced, distributed and consumed were subject to increasing change. Historically, the production of cultural works was organised along the lines of religious and aristocratic forms of patronage. Herein, cultural producers were bound to their patrons and one another through local networks of direct and personal relations. As the century progressed, patronage was undermined and replaced by a system of capitalist relations and markets presided over by emergent forms of 'subscription' and 'commercial' publishing (Brantlinger, 1998). By the final third of the $18^{\text {th }}$ century, the production and consumption of cultural goods among the educated classes was increasingly mediated through networks of impersonal and instrumental relations. These emergent networks were organised around abstract economic values and the pursuit of commercial success (Keen, 1999).

Particularly significant in this regard was the crystallization of a new middle-class readership and 'the industrial and commercial restructuring of the 'literary' field [which] include[d] printers, publishers, reviewers, booksellers, readers and of course authors' (Brantlinger, 1999: 12). Changes to the ways cultural goods were produced and consumed opened up new channels for upward social mobility (Kelly, 1989). An emergent class of professional bourgeois authors motivated by the opportunity to accumulate large amounts of economic and symbolic capital e.g. status, notoriety, acclaim etc. were called forth. The number of printing houses in London, such as William Lane's notorious Minerva Press, steadily increased in number. The cultivation of reading habits facilitated by travelling libraries and rising levels of literacy comprised similarly important developments, feeding directly into the rising demand for novels and romances on the part of a crystallizing middle-class readership (Williams, 1961).

It was in the spaces opened up by commercial and subscription forms of publishing that the Gothic depiction of Italy began to take shape. According to Punter (1996), the emergence of the Gothic novel cannot be understood without reference to the genesis of the novel form itself. The Gothic novel was consecrated by, while working to consolidate, the emergent field of novelistic production. At the hands of the Gothic authors, most notably Mrs Radcliffe and Matthew Lewis, Italy was transmogrified into a land of picturesque and remotely situated castles, 'moonlit nights, wicked Catholic clerics... Italian settings, beautiful persecuted heroines, dark villains and catalogues of horror' (Le Tellier, 1980: 2). Radcliffe's success and dominance within the field became a model that 'spawned a whole series of minor but vigorous novels in the early years of the nineteenth century...[that]...attempt to reproduce the commercially successful formula' (Churchill 1980: 18). Novels such as: Lewis's The Bravo of Venice (1805), Edward Montague's The Legends of a Nunnery (1807), and Anne Hatton's The Oath of Vengeance (1819) (Marshall 1934: 256).

The Gothic rendering of Italy represents an important moment in the romantic depiction of Italy, refracting tensions in the relations between the emergent class of commercially-oriented bourgeois authors and aristocratic and conservative writers and poets. The Gothic novel opened up a discursive space in which a distinctively bourgeois response to the wider social, political and religious changes of the period was formulated (Kelly, 1989; Demata, 2006). Specifically, in ways which capture the ambivalence of the bourgeois authors towards those above them e.g. their social and artistic superiors, and those beneath them e.g. the undistinguished mass. The use and appropriation of Italy and Italian themes on the part of a class of writers not possessed of the means to undertake the Tour of Italy forms part of a self-conscious attempt to emulate the cultural proclivities of their social superiors. That the Gothic novels were set in Southern Italy, largely unexplored and unknown to British tourists, provided authors with an unspoiled imaginative terrain on which to think through and consolidate the coordinates of an emergent bourgeois subjectivity (Demata, 2006).

The Gothic rendering of Italy was a necessary but not sufficient condition of possibility for the romantic treatment of Italy (Le Tellier, 1980). This is so in a number of ways. First, the majority of the romantic poets, including Byron and Shelley, had read and were influenced by the work of the Gothic novelists (Marshall 1934; 
Churchill 1980). Second, the use of supernatural themes and motifs as devices for escaping the wider social and political anxieties of the period contributed to the wider evolution of romantic discourse. In particular, the growing consensus as to the importance of 'Imagination' as a creative faculty. Third, the focus on Southern Italy and preindustrial forms of community understood to be outside of the sweep of the Enlightenment served to consolidate the alleged 'authenticity' of traditional forms of social relations. Fourth, the Gothic rendering of Italy, the novel form through which it was realised, and the class of professional bourgeois writers from whose pens it derived, all served as negative points of reference against which the romantic poets sought to reconfigure and reclaim the ideals of 'Art' and 'Artist'.

Notwithstanding that 'the horror novel... affects all the great romantics without exception', publically its status as a genre was condemned by romantic poets and conservative critics (Rodway, 1963: 59). The commercial success of the Gothic novel was read as symptomatic of the wider threat of literacy among an unguided and poorly educated reading public on the one hand, and the professionalization and commercialisation of 'literature' on the other (Valenza, 2009). The status of poetry in particular, understood as the supreme art form and guarantor of the distinctiveness of a national culture and language, was perceived as under threat (Valenza 2009; Williams, 1958). It was against the backdrop of these changes, referred to by Thomas Carlyle as 'industrialism', that the Romantic category of the Artist was forged (Williams, 1961: 85).

The romantic poets were vociferous in their attempts to reassert themselves and their art form as unique within, if not wholly distinct from, those engaged in the wider cultural division of labour. Prominent poets such as Coleridge and Wordsworth vigorously asserted the difference between the calling of the poet and all other forms of professional career. It is with the Romantic poets that the prevailing conceptions of the 'poet and poetic faculties' are transformed (Keith, 2001: 286). Poets are not made; rather, they comprise constitutionally different types of human being altogether (Valenza, 2009).

The category of Artist forms part of the wider process of self-realization of creative producers who actively sought to represent and promote themselves in more distinctive and self-serving ways (Inglis and Hughson, 2005: 16). The vision of the romantic Artist as a unique and almost divinely gifted individual was a direct attempt to reclaim the identity and the status of Art from the mechanized and fragmented nature of work under the conditions of a rapidly industrialising capitalist society. It is in this context that the category of the Artist comes to assume the figure of a driven but lonely and socially dislocated figure, marginalised from and opposed to the stuffy and conservative conventions of respectable bourgeois society (Williams, 1961: 85). The concept of 'skill' in relation to the category of Artist came to be displaced by that of 'sensibility' during this time too (Williams, 1983 [1958]).

\section{ITALY AND THE ITALIANS IN BYRON AND SHELLEY}

In the poetic works of Byron and Shelley, pre-existing forms of discourse are revised, reconfigured and used to reconstruct Italy and the Italians in a range of novel and distinctly positive ways. Aristocrats by birth, both Byron and Shelley acquired high levels of classical learning and knowledge of English literature during their time at England's elite educational institutions. During their time at the Universities of Cambridge and Oxford respectively, the poets were exposed to a number of prominent literary circles. Entry into these literary circles brought Byron and Shelley into contact with a number of prominent Italian poets who had quit Italy for England. Now living in exile in England, the Italian poets introduced Byron and Shelley to and cultivated within them a greater knowledge and appreciation of the work of the 'Italian bard', Dante Alighieri (1265 - 1321). As both man and poet, the figure of Dante provided rich inspiration for Byron and Shelley as well as the subsequent generation of romantic poets, writers and painters (Churchill, 1980).

Dante's appeal to the English romantics operates on two main levels. First, as a political dissident and fugitive forced to flee his native Florence, the self-sacrificing spirit in which Dante lived and worked appealed greatly to the romantic poets. Here was a poet prepared to die in exile for his art. And second, it was on account of his outsider status that the exiled Italian poets living in England sought to play up Dante's reputation as the supreme exponent of the Italian language. The depiction of Dante as both exile and poetic genius appealed greatly to Byron. Born with a club-foot, subject to troubled familial relations and forced exclusion from his natural aristocratic milieu, the figure of the exiled genius was one with whom Byron felt a powerful affinity. As Vassallo (1984: 37) notes, the appeal of Dante to Byron was as much the magnitude of his 'poetical achievement as...the fact that he was a martyr to his high principles... an exile himself. In Shelley, the influence of Dante is most notable in the style in which the poems Prometheus Unbound (1820), Epipsycbidion (1821), Adonais (1821), and the Triumph of Life (1822) are composed and written, whereas his Ode to the West Wind (1819), inspired by and written in the Italian countryside, draws on Dante's style of the terza rima (Reiman and Powers, 1977).

The fertility of 'Italian literature exerted a strong influence on the narrative style and versification of the Romantic poets' (Saunders, 2004: 350). An appreciation of Italian literature, themes and poetic forms, is central to the poetic verse of Byron and Shelley and subsequent romantic depictions of Italy as evidenced in the work of the 
members of the Pisan Circle 4 . More broadly, English romantic poetry placed great emphasis on creativity and innovation, not only in terms of genre but also 'all that was involved in its design as verbal artefact' (O' Neill 2004: 275). Rarely adhering to established poetic models, the romantic poets preferred instead to use and appropriate their materials by altering them in novel and expressive ways. Hybrid poetic forms, along with a renewed interest in epic poetry, poetic drama, lyric poetry and poetic narrative, grew and flourished under the romantics. A key development facilitating the rise of the lyric form was the popularity 'of a literary and popular culture rich in song' (Saunders 2004: 311). Use of the 'lyric' and 'narrative' form features extensively in Byron and Shelley's Italian works. It is via the poets' Italian works that that the lyric form assumes 'its modern cultural role as the poetic voice of the individual self (Saunders 2004: 318). Shelley's Adonais, for example, is an elegiac variation of the extended lyric form undertaken in the style of Spenserian stanzas.

Thematically, a central facet of romantic literature and poetry is an intense concern with Nature and natural phenomena more generally as a source of aesthetic beauty and moral and spiritual edification (Berlin, 1999). Particularly influential for shaping these concerns were Edward Burke's A Pbilosophical Enquiry into the Origins of our Ideas of the Sublime and Beautiful (1756) and William Gilpin's An Essay upon Prints: Containing Remarks Upon The Principles of Picturesque Beanty (1768). Within the field of poetry, the turn towards natural phenomena as a source of emotional, as opposed to intellectual creative inspiration, forms the context in which poets such as John Dyer (1699 - 1757), James Thomson (1700 - 1748) and Thomas Gray (1716 - 1771) broached the natural landscape as subject matter. In Wordsworth's, Lyrical Ballads (1798), appreciation of England's natural landscape reached its apotheosis (Manwaring 1967: 96). In the work of the pre- and romantic English poets, the lyric form is brought to bear on the English countryside and a range of natural phenomena. In Byron and Shelley, the lyric form, along with a range of Italian-inspired poetic styles and devices, are adapted and put to work on the Italian natural scene and Italian themes. It is travel to Italy, and immersion within the natural beauty of the Italian countryside specifically, that are represented as spiritually and artistically transformative.

Thus far we have established how and why the type of habitus and capitals acquired by Byron and Shelley shaped their respective trajectories through the cultural field and how in turn this enabled them to assume dominant positions within the field of poetry. Notwithstanding the poets' bankruptcy, that they were both were able to generate enough income to quit England for Italy ${ }^{5}$ and were well received within Italian society (Byron more so than Shelley), is highly significant for understanding the similarities and differences in the poets respective position-takings. Typically in ways which served to advance the dominant positions they had attained to and were subsequently able to consolidate in self-serving ways. Key here is the way both Byron and Shelley draw on, revise and re-appropriate, various negative discursive constructions of Italy, contemporary Italian culture and the Italian people, as vehicles for critically evaluating changes taking place in England at the time. Particularly as they relate to the nature and status of poetry and the romantic poet as the supreme expression of the Artist.

Central to Byron and Shelley's Italian poetic works is the depiction of Italy and contemporary Italian culture as all that England is not. Drawing on and revising a range of pre-existing negative forms of discourse, Byron and Shelley (re-)construct Italy and the Italians through a range of positive and novel discursive forms. To increase their dramatic effect, the poets (re-)organise their framing of Italy around a series of arresting juxtapositions centring on different aspects of England, including: the natural scenery and landscape; history; social conventions and pre-industrial way of life; language; and temperate climate. Italy is re-constructed as Europe's premier location for poetic (read artistic) meditation, a life-affirming alternative to the oppressive and stifling Puritanism of industrialising England. The discourse of Italy as a picturesque, natural idyll, a discourse arising earlier in the century in the fields of landscape painting and then poetry, is taken up and enlarged to incorporate notions of 'refuge'. On the one hand, Italy is aesthetically beautiful, picturesque and temperate, providing refuge from the smog-ridden bleakness of industrialising England, a land described by Keats 'as continually under hatches... a region of Mists' (Foreman, 1935: 135). On the other, Italian society is free from the stifling and oppressive dictates of upper-class social norms and conventions.

Having both quit England for Italy, Byron and Shelley appropriate the distance between themselves, England, and the 'vulgar' class of professional writers and poets living and working there, to draw to attention the enhanced conditions in which their 'art' is realised. Italy is recast as host to a rich array of life-affirming sensory pleasures, the like of which are denied to the professional writers and poets back in England. The inspirational qualities of the Italian landscape are extended beyond its natural elements so as to incorporate the historical remnants of

\footnotetext{
${ }^{4}$ The term 'Pisan Circle' refers to an informal network of English poets and writers who left England for Italy and took up residence in Pisa both during the time of, and in some cases after, the period of Shelley's residence there (approximately 1820 - 1822). The Pisan circle included Lord Byron, Leigh Hunt (writer and poet) and Edward Trelawney (novelist and writer) to name but the most prominent members. See Schoina (2009) for an in-depth treatment of the Pisan Circle and the influence both Percy Bysshe Shelley and Mary Shelley had for shaping the discursive accounts of Italy and the Italians associated with its members.

${ }^{5}$ Byron and Shelley left England for Italy in 1816 and 1818 respectively, never to return.
}

$10 / 15$

(C) 2019 by Author/s 
antiquity. Reconceived in this way allows Byron and Shelley to assert the uniqueness of Poetry as the supreme art form and the Poet as the boldest expression of the creative Artist (Thorpe, 2013). The conception of the Artist as a constitutionally different type of human being is interwoven into a range of discursive representations centring on the transformative capacities that exposure to Italy, the Italian natural scene and life-affirming culture are alleged to inspire. Only in Italy, a land so rich in natural beauty and steeped in history and culture, can the inspiration for true Art be realised; and only through realising one's innate creativity faculties in an Italian setting is it possible to lay claim to the lofty ideal of the romantic Artist.

Inheriting the upper-class deference towards Italy's classical past, Byron and Shelley re-appropriate the classical ruins as vehicles for poetic meditation. Italy provides a privileged backdrop for the 'emerging romantic sensibility and the preferred setting for a 'poetry of ruins' that reached its climax in...Byron and Shelley' (Springer, 1987: 1). While both poets prized the relics and ruins as living testimony to ancient civilizations, they elaborate and extend their meaning in divergent ways. Whereas Gibbon saw in the ruins of ancient Rome testimony to the sic transit of fallen Empires, Byron elevates this sentiment to the plane of human existence. At the hands of Byron, Italy's Roman ruins become metaphors for the human condition: no other setting in Europe could provide such an arresting sense of the bathetic contrast between the everlasting 'immortality of art' and the fleeting 'mortality of genius' (Churchill, 1980: 2). By contrast, Shelley felt positively inspired and comforted by the proximity of a ruinous past with which he felt a far greater spiritual affinity than the industrialising present of England (Weinberg, 1990: 14).

Where Byron and Shelley diverge most notably is in their experience and representation of the contemporary Italians. Byron's relations with the Italian people were typically direct and personal; Shelley's were largely abstract and impersonal. Byron conducted numerous sexual liaisons with Italian women while in Italy, kept the company of Italian high-society when in Venice, and actively shunned the company of English tourists to the peninsula who sought him out. It was via his love affair with the Italian countess, Teresa Guiccioli, that Byron was recruited into the revolutionary Carbonari Movement, a secret society devoted to liberating Italy from foreign suzerainty. In Byron, the sensory and affective indulgences of the Italian people and Italian way of life more generally, are read as testimony to the life-affirming qualities of pre-industrial forms of human relations, from which he believed more 'natural' and 'authentic' modes of being flowed forth. While the political plight of the Italian people is central to a number of Shelley's poetic works, nonetheless his concern reflects the broader romantic interest in ideal notions of 'Freedom' and 'Liberty' (Berlin, 2000) rather than a genuine, heart-felt empathy. Of the Italian people, Shelley was openly reproachful. He was particularly scathing of Italian women, referring to them as 'perhaps the most contemptible of all who exist under the moon; the most ignorant, the most disgusting, the most bigoted, the most filthy' (Jones 1964: 504, vol. II).

In summary, the positive reconstruction of Italy and the Italians in the poetic works of Byron and Shelley marks a key moment in late 18th century and early $19^{\text {th }}$ century discursive representations of the peninsula and its people in England. The associative ties Bryon and Shelley forge between the pre-industrial and life-affirming qualities of contemporary Italian life on the one hand, and notions of creative inspiration, sensory indulgence and artistic authenticity on the other, worked to enhance the perceived value of Italian travel within the field of Art throughout the $19^{\text {th }}$ century. Reconstituted in such positive and edificatory terms, the perceived value of Italian travel as an indispensable form of 'capital' necessary for the realisation of the artistic habitus comes to assume doxic status. Testimony to the transformative powers Italy and Italian culture were understood to possess, can be gleaned from even the most cursory glance of the list of writers, painters, poets, sculptors etc. who travelled to and spent time in Italy during the $19^{\text {th }}$ century e.g. Rossetti, the Brownings, Ruskin, E.M. Forster and D.H. Lawrence, to name but the most prominent. This is not to suggest that discursive practices which positioned Italy and the Italians as inferior or lacking in various senses, ceased to exist or diversify - they did and in a variety of historically novel areas too. Rather, the point to emphasise here is that it was against the backdrop of a diverse range of positive, as opposed to negative, discursive constructions of Italy within $19^{\text {th }}$ century English culture were forged and took shape.

\section{CONCLUSIONS}

This article contends that the subject of cultural representation has been normatively overdetermined and insufficiently theorized. Following in the wake of Edward Said's Orientalism, social-scientific accounts of cultural representation have been dominated by a one-sided and partisan conception of discursive constructions of the other and otherness as sites marked out primarily for the negative expression of power. Some forty years on, and Said's Orientalism remains a powerful and legitimizing point of reference underwriting a range of analytically limiting and delimited account of cultural representation. In privileging normativity over analytical acuity, scholarly analysis has neglected to acknowledge the generative effects negative discourses have for shaping their positive counterparts and the contexts in which they are formed. A further corollary of this situation is that attempts to 
account for the mechanisms driving continuity and change in the discursive construction of the cultural other have been significantly overlooked and under-theorized.

Drawing on the case of discursive representations of Italy and the Italians in England from 1680 to 1830, this article has sought to demonstrate the merits of field theory as the basis for a more comprehensive and analytically differentiated account of cultural representation. Claims to 'know' and represent the other comprise forms of capital relative to fields. The type of habitus and capitals intimately inform the discursive parameters of the categories through which the other is brought into view and constituted. Whether or not agents are disposed towards representing the cultural other negatively and or positively is contingent on the variable conditions of fields. Arising at the point of intersection between a socially-marked habitus and field position, discursive representations of the other refract the relations of conflict and cohesion characteristic of the fields in which they are produced, the position of the producer therein, and the position of the field in the wider architecture of fields. Whether or not forms of discursive representation are reproduced, revised and or rejected, is contingent on the structure of fields and the structure of relations through which fields are conjoined.

Critical normative forms of theoretical discourse comprise merely one way of constituting the terrain of cultural representation. As this article has demonstrated, field theory opens up a more analytically differentiated and historically-oriented vista from which to survey that terrain. With this in mind, two avenues for future research into cultural representation seem particularly pressing. Firstly, what would an alternative account of Western representations of the 'Orient' based on field theory look like, and how might it be used to reframe debate and disputation in this area? And secondly, how might a model of cultural representation based on field theory be used to recognise and problematize the analytical significance of positive discursive constructions of the other and otherness? In other words, if discourse brings into being and constitutes the other in relatively arbitrary ways, why have particular cultural others - in this case Italy and the Italians as they have been represented in England - been understood and represented in largely positive and laudatory ways? Given that at the time of writing the European Union is preparing to leave Britain, the task of capturing the conditions under which the other comes to be positively understood and represented seems more pressing than ever.

\section{REFERENCES}

Ahmad, A. (1992). Orientalism and After: Ambivalence and Cosmopolitan Location in the Work of Edward Said. Economic and Political Weekly, 27(3), 98 - 166.

Ahmad, A. (1993). Orientalism and After, in P. Williams and L. Chrisman (eds), Colonial Discourse and Post-Colonial Theory: A Reader (pp. 162 -171). London: Routledge.

Alexander, J. (2003). The Meanings of Social Life: A Cultural Sociology. Oxford: Oxford University Press. https:// doi.org/10.1093/acprof:oso/9780195160840.001.0001

Ayers, P. J. (1997). Classical Culture and the Idea of Rome in the Eighteenth Century. Cambridge: Cambridge University Press.

Berlin, I. (2000). The Roots of Romanticism. London: Pimlico.

Black, J (1992). The British Abroad: The Grand Tour in the Eighteenth Century. Gloucestershire: Sutton Publishing Limited.

Black, J. (2003). Italy and the Grand Tour. New Haven: Yale University Press. https://doi.org/10.1057/9780230287242

Black, J. and Gregory, J. (1991). Culture, Politics and Society in Britain 1660 - 1800. Manchester: Manchester University Press.

Bourdieu, P. (1986). The Forms of Capital, in J. Richardson (ed.), Handbook of Theory and Research for the Sociology of Education (pp. 241 - 58). New York: Greenwood.

Bourdieu, P. (1990). The Logic of Practice. Cambridge: Polity.

Bourdieu, P. (1993). The Field of Cultural Production: Essays on Art and Literature. New York: Columbia University Press.

Bourdieu, P. (1995). The Rules of Art: Genesis and Structure of the Literary Field. Stanford, CA: Stanford University Press.

Bourdieu, P. (2000). Pascalian Meditations. Oxford: Polity Press.

Bourdieu, P. and Wacquant, L. J. D. (1992). An Invitation to Reflexive Sociology. Chicago. University of Chicago Press.

Brantlinger, P. (1998). Reading Lesson: The Threat of Mass Literacy in Nineteenth-Century British Fiction. Bloomington: Indiana University Press.

Cassano, F. (2012). Southern Thought and Other Essays on the Mediterranean. Fordham: Fordham University Press. https://doi.org/10.5422/fordham/9780823233649.001.0001 
Chibber, V. (2018). The Dual Legacy of Orientalism, in B. Abu-Manneh (ed.), After Said: Postcolonial Literary Studies in the Twenty-First Century, (pp. 37 - 52). Cambridge: Cambridge University Press. https://doi.org/10.1017/9781108554251.003

Chovanec, J. and Molek-Kazakow, K. (2017). Representing the Other in European Media Discourses. John Benjamins Publishing Company. https:/ / doi.org/10.1075/dapsac.74

Churchill, K. (1980). Italy and English Literature 1764 - 1930. London: The MacMillan Press Ltd. https://doi.org/10.1007/978-1-349-04642-3

Clark, J.C.D. (1985). English Society 1660 - 1832: Religion, Ideology and Politics during the Ancien Regime. Cambridge: Cambridge University Press.

Clifford, J. (1988). The Predicament of Culture: Twentieth Century Ethnography, Literature and Art. Harvard: Harvard University Press. https://doi.org/10.2307/j.ctvjf9x0h

Dalby, A. (2000). Empire of Pleasures: Luxury and Indulgence in the Roman World. London: Routledge.

Demata, M. (2006). 'Italy and the Gothic', Gothic Studies, 8(1): 1 - 9. https://doi.org/10.7227/GS.8.1.2

Dirks, N. B. (2004). Edwards Said and Anthropology, Journal of Palestine Studies, $33(3), 38$ - 54. https://doi.org/10.1525/jps.2004.33.3.038

Foreman, M. B. (1935). The Letters of John Keats. Oxford: Oxford University Press.

Foucault, M. (1984 [1968]). What is an Author? in P. Rabinow (ed.), The Foucault Reader: An Introduction to Foucault's Thought (pp.101 - 120). New York: Pantheon Books.

Foucault, M. (2002 [1969]). Archaeology of Knowledge. London: Routledge.

Go, J. (2013a). For A Postcolonial Sociology, Theory and Society, 42(1), 25 - 55. https://doi.org/10.1007/s11186012-9184-6

Go, J. (2016). Postcolonial Thought and Social Theory. Oxford: Oxford University Press. https://doi.org/10.1093/acprof:oso/9780190625139.001.0001

Go, J. and Krause, M. (2016). Fielding Transnationalism: An Introduction, The Sociological Review Monographs, 64(2), 6-30. https://doi.org/10.1002/2059-7932.12000

Gorski, P. S. (2013). Bourdieu and Historical Analysis. London: Duke University Press. https://doi.org/10.1215/9780822395430

Guhin, J. and Wyrtzen, J. (2013). The Violences of Knowledge: Edward Said, Sociology, and Post-Orientalist Reflexivity, in J. Go. (ed.) Postcolonial Sociology (Political Power and Social Theory), Vol. 24, (pp. 231 - 262). Bingley: Emerald Group Publishing Limited. https:/ / doi.org/10.1108/S0198-8719(2013)0000024015

Highet, G. (1949). The Classical Tradition: Greek and Roman Influences on Western Literature. USA: Oxford University Press.

Inglis, D. and Hughson, J. (2005). The Sociology of Art: Ways of Seeing. Hampshire: Palgrave MacMillan. https://doi.org/10.1007/978-1-137-04494-5

Iskandar, A. and Rustom, H. (2010). Introduction: Emancipation and Representation, in A. Iskander and H. Rustom (eds), Edward Said: A Legacy of Emancipation and Representation (pp. 1 - 22). University of California Press, Berkley.

Joffe, A. H. (2007). For Lust of Knowing: The Orientalists and their Enemies, Transaction: Social Science and Modern Society, 44(4), $74-79$.

Johnson, J.W. (1967). The Formation of English Neo-Classical Thought. Princeton: Princeton University Press. https://doi.org/10.1515/9781400877485

Jones, F. L. (1964). The Letters of Percy Bysshe Shelley. Oxford: Oxford University Press.

Keen, P. (1999). The Crisis of Literature in the 1790s: Print Culture and the Public Sphere. New York: Cambridge University Press. https://doi.org/10.1017/CBO9780511484339

Keith, J. (2001). Pre-Romanticism' and the ends of Eighteenth Century Poetry, in J. Sitter (ed.) The Cambridge Companion to Eighteenth-Century Poetry (pp. 271 - 290). Cambridge: Cambridge University Press. https:// doi.org/10.1017/CCOL0521650909.013

Kelly, G. (1989). English Fiction of the Romantic Period, 1789 - 1830. London: Longman.

Kennedy, V. (2000). Edward Said: A Critical Introduction. Oxford: Polity Press.

Khare, R. S. (1990). Indian Sociology and the Cultural Other, Contributions to Indian Sociology, $24(2), 177$ - 199. https://doi.org/10.1177/006996690024002003

Krause, M. (2018). How Fields Vary, British Journal of Sociology, 69(3), 3 - 22. https://doi.org/10.1111/14684446.12258

Lane-Fox, R (2006). The Classical World: An Epic History of Greece and Rome. London: Penguin.

Le Tellier, R.I. (1980). An Intensifying Vision of Evil: The Gothic Novel (1764 - 1820) As A Self-Contained Literary Cycle. Salzburg: Institut fur Anglistik und Amerikanistik, Universitat Salzburg.

Leffler, P.K. (1978). From Humanist to Enlightenment Historiography: A Case Study of Francois Eudes de Mezeray, French Historical Studies, 10(3), 416 - 438. https:/ / doi.org/10.2307/286338 
Lewis, H.S. (2007). The Influence of Edward Said and Orientalism on Anthropology, Israeli Affairs, 13(4), 774 785. https://doi.org/10.1080/13537120701445158

Lewis, H.S. (2008). The Misrepresentation of Anthropology and its Consequences, American Anthropologist, 100(3), 716 - 731. https://doi.org/10.1525/aa.1998.100.3.716

Ogilvie, R. M. (1964). Latin and Greek: A History of the Influence of the Classics on English Life from 1600 to 1918. London: Routledge \& Kegan Paul.

Ousby, I. (1990). The Englishman's England: Taste, Travel and the Rise of Tourism. Cambridge: Cambridge University Press.

Pocock, J. G. A. (1993). The Varieties of British Political Thought: 1500 - 1800. Cambridge: Cambridge University Press.

Porter, D. (1993). Orientalism and its Problems, in P. Williams and L. Chrisman (eds), Colonial Discourse and PostColonial Theory: A Reader (pp.150 - 161). London: Routledge.

Punter, D. (1996). The Literature of Terror: A History of Gothic Fictions from 1765 to the Present Day. New York: Longman.

Reed, I. A. (2013). Power: Relational, Discursive, and Performative Dimensions, Sociological Theory, 31(3), 193 218. https://doi.org/10.1177/0735275113501792

Reiman, D. H. and Powers, S. B. (1977) Shelley's Poetry and Prose: Authoritative Texts, Criticism. New York: Norton.

Rodway, A. E. (1963). The Romantic Conflict. London. Chatto \& Windus.

Said, E. (1987). Edward Said, in I. Salusinszky (ed.), Criticism in Society: Interviews with Jacques Derrida, Northrop Frye, Harold Bloom, Geoffrey Hartman, Frank Kermode, Edward Said, Barbara Johnson, Frank Lentricchia, and J. Hillis Miller (pp. 123 -148). New York, London: Methuen.

Said, E. (2005 [1978]). Orientalism. London: Penguin Books.

Sapiro, G. (2012). Autonomy Revisited: The Question of Mediation and its Methodological Implications, Paragraph, 35(1), 30 - 48. https:// doi.org/10.3366/para.2012.0040

Sax, W.S. (2007). The Hall of Mirrors: Orientalism, Anthropology and the Other, American Anthropologist, 100(2), 292 - 301. https://doi.org/10.1525/aa.1998.100.2.292

Schiona, M. (1999). Romantic 'Anglo-Italians': Configurations of Identity in Byron, Shelley and the Pisan Circle. Burlington: Ashgate.

Sena, F. (1968). Smollett's Persona and the Melancholic Traveller, Eighteenth Century Studies, 1(4), 353 - 369. https://doi.org/10.2307/2737856

Simonini, R. C. (1952). Italian Scholarship in Renaissance England. Chapel Hill: The Orange Printshop.

Smollett, T. (2010 [1766]). Travels Through France and Italy. London: Taurus Parke Paperbacks.

Solkin, D. (1993). Painting For Money: The Visual Arts and the Public Sphere in Eighteenth Century England. Yale: Yale University Press.

Spadafora, D. (1990). The Idea of Progress in Eighteenth-Century Britain. New Haven: Yale University Press.

Springer, C. (1987). The Marble Wilderness: Ruins and Representation in Italian Romanticism, 1775 - 1850. New York: Cambridge University Press.

Steinmetz (2008). The Colonial State as a Social Field: Ethnographic Capital and Native Policy in the German Overseas Empire before 1914, American Sociological Review, 73(4), 589 - 612. https:// doi.org/10.1177/000312240807300404

Steinmetz, G. (2007). The Devil's Handwriting: Precoloniality and the German Colonial State in Qingdao, Samoa, and Soutbwest Africa. Chicago: University of Chicago Press. https://doi.org/10.7208/chicago/9780226772448.001.0001

Thorpe, C. (2009). Beyond 'La Dolce Vita': Bourdieu, Market Heteronomy and Cultural Homogeneity, Cultural Sociology, 3(1), 123 - 146. https://doi.org/10.1177/1749975508100674

Thorpe, C. (2013). The Poetics of Travel in Byron and Shelley: Translating Italian Experience into Artistic Distinction, in A. Yarrington, S. Villani and J. Kelly (eds) Travels and Translations: Anglo-Italian Cultural Translations (pp. 181 - 204). New York: Rodopi.

Turner, B. (1989). From Orientalism to Global Sociology, Sociology, 23(4), 629 - 638. https://doi.org/10.1177/0038038589023004007

Turner, B. (1994). Orientalism, Post-Modernism and Globalism. London: Routledge. https://doi.org/10.4324/9780203427255_chapter_1

Turner, K. (2001). British Travel Writers in Europe 1750 - 1800: Authorship, gender and National Identity. Aldershot: Ashgate.

Valenza, R. (2011). Literature, Language, and the Rise of the Intellectual Disciplines in Britain, 1680 - 1820. Cambridge: Cambridge University Press.

Varisco, D.M. (2007). Reading Orientalism: Said and the Unsaid. Washington: University of Washington Press. 
Weinberg, A. M. (1990). Shelley's Italian Experience. London: MacMillan. https:/ / doi.org/10.1007/978-1-349-216499

Williams, R. (1961). The Long Revolution. Harmondsworth: Penguin. https:// doi.org/10.7312/will93760

Williams, R. (1983 [1958]). Culture and Society, 1780 - 1950. London: Chatto \& Windus. 